\title{
HUBUNGAN ANTARA ANEMIA DAN PRESTASI BELAJAR DENGAN INDEKS MASSA TUBUH PADA REMAJA PUTRI KELAS VIII DI SURAKARTA
}

\section{THE CORRELATION BETWEEN ANEMIA AND LEARNING ACHIEVEMENT WITH BODY MASS INDEX IN ADOLESCENT CLASS VIII AT SURAKARTA}

\author{
Endang Widhiyastuti ${ }^{1}$ \\ dr.endangwidhiyastuti@yahoo.co.id \\ ${ }^{1}$ Laboratorium Hematologi, D-IV Teknologi Laboratorium Medis, STIKES Nasional, Surakarta
}

\begin{abstract}
Abstrak
Remaja usia 13-15 tahun termasuk masa peralihan dari remaja awal ke remaja akhir yang merupakan masa pencarian identitas sehingga mudah terpengaruh lingkungan sekitar. Oleh karena itu, remaja berisiko tinggi mengalami gangguan gizi karena pada usia remaja mengalami peningkatan kebutuhan zat gizi, kebiasaan membatasi konsumsi makan dan pola konsumsinya yang sering menyimpang dari kaidah ilmu gizi.Status gizi dan anemia adalah faktor yang berpengaruh terhadap perkembangan otak. Kerusakan otak akibat gangguan gizi menyebabkan gangguan kognitif, perkembangan IQ terhambat dan kemampuan belajar terganggu yang selanjutnya berpengaruh pada prestasi belajar. Tujuan: Penelitian ini bertujuan untuk mengetahui hubungan antara anemia dan prestasi belajar dengan indeks massa tubuh (IMT) pada remaja putri kelas VIII di Surakarta.

Metode penelitian: Desain penelitian yang digunakan adalah observasional dengan pendekatan cross sectional, populasi remaja putri SMP Negeri 3 dan SMP Negeri 7 Surakarta semester genap tahun 2015, berusia 13-15 tahun. Subjek penelitian berjumlah 120 yang diambil secara random sampling. Data diperoleh melalui kuesioner, status gizi diukur dengan z-score. Anemia diukur dengan kadar $\mathrm{Hb}$ menggunakan metode cyanmethemoglobin. Prestasi belajar diukur dari nilai ujian akhir semester. Selanjutnya data-data yang terkumpul diolah dengan menggunakan analisis bivariat.

Hasil penelitian: Didapatkan nilai $r=0,201$, odd rasio sebesar 4,255 dan $p=0,35$, hal ini berarti terdapat hubungan antara anemia dengan IMT pada remaja putri SMP kelas VIII. Sedangkan hubungan antara prestasi belajar dengan IMT remaja putri kelas VIII didapatkan hasil $r=0.093$ dengan odd rasio $=0,307$ dan $p=0.999$. Hal ini berarti tidak ada hubungan antara prestasi belajar dengan IMT. Kesimpulan: Terdapat hubungan yang bermakna antara IMT dengan anemia Tidak ada hubungan antara IMT dengan prestasi belajar

Kata Kunci : status gizi, anemia, prestasi belajar, remaja putri
\end{abstract}

\begin{abstract}
Adolescents aged 13-15 years old were transition from early adolescence to late adolescence which is a period of identity search so easily affected the surrounding environment. Therefore, adolescents at high risk of nutritional disorders because in adolescents experienced increased nutritional needs, the habit of limiting the consumption of food and consumption patterns that often deviate from the rules of nutrition science.Status nutrition and anemia are factors that affect the development of the brain. Brain damage due to nutritional disturbances leads to cognitive impairment, impaired IQ development and impaired learning abilities that subsequently affect learning achievement. Objective: This study aims to determine the
\end{abstract}


correlation between anemia and learning achievement with body mass index (BMI) in adolescent girls of class VIII in Surakarta.

Research method: The research design used was observational with cross sectional approach, the population of junior high school girls 3 and SMP Negeri 7 Surakarta even semester of 2015/2016, aged 13-15 years. Research subjects amounted to 120 taken by random sampling. Data obtained through questionnaire, nutritional status measured by z-score. Anemia was measured by $\mathrm{Hb}$ levels using cyanmethemoglobin method. Learning achievement is measured from the final exam score. Furthermore, the collected data is processed by using bivariate analysis.

Result of research: The value of $r=0,201$, odd ratio 4,255 and $p=0,35$, this means there was correlation between anemia with body mass indeks (IMT) in junior high school girl of class VIII in Surakarta. While the relation between learning achievement with IMT class of females VIII obtained $r=0.093$ with odd ratio $=0,307$ and $p=0999$. This means there was no relationship between learning achievement and BMI. Conclusion: There is a significant relationship between BMI with anemia No relation between IMT and learning achievement.

Keywords: nutritional status, anemia, learning achievement, young women

\section{Pendahuluan}

Status gizi merupakan pilar utama dari kesehatan dan kesejahteraan, meningkatnya status gizi masyarakat digunakan sebagai penentu dasar pembentukan sumber daya manusia yang berkualitas (Depkes RI, 2010). Salah satu sumber daya manusia dalam suatu negara dalam pembangunan adalah remaja (Ristianingrum, 2010).

Parameter kualitas sumber daya manusia dapat dilihat salah satunya melalui prestasi belajar. Dalam sistem pendidikan formal di Indonesia, indikator prestasi belajar ditentukan berdasar tiga hal, yaitu aspek kognitif, aspek afektif, dan aspek psikomotor anak didik (Nurhadi, 2004). Prestasi belajar dipengaruhi oleh kadar hemoglobin, kondisi umum jasmani, status gizi dan tonus otot (Syah, 2010).

Status gizi adalah pilar utama kesehatan dan kesejahteraan selama siklus kehidupan, dengan meningkatnya status gizi masyarakat menggambarkan banyaknya sumber daya manusia yang berkualitas (Depkes RI, 2010). Kualitas sumber daya manusia yang meningkat menunjukkan adanya peningkatan prestasi belajar yang meningkat. Prestasi belajar dalam sistem pendidikan Indonesia dititik fokuskan pada kecerdasan kognitif. Aspek kognitif adalah aspek yang berkaitan berkaitan erat dengan tingkat Intelligence Quotient (IQ) atau kemampuan berpikir peserta didik (Nurhadi, 2004). Kecerdasan kognitif berkaitan erat dengan status gizi seseorang (Hardinsyah, 2012). Apabila seseorang mengalami status gizi kurang akan dapat mengganggu motivasi anak, kemampuannya untuk berkonsentrasi, kurang dan kesanggupannya untuk belajar juga berkurang (Khomsan, 2010).
Masa remaja (adolescence) adalah periode transisi dari masa anak ke dewasa (Depkes, 2010) dimana mereka memerlukan kebutuhan gizi yang khusus (Tim Penulis Poltekkes Depkes Jakarta I, 2010) untuk pertumbuhan dan perkembangannya (Soetjiningsih, 2012). Remaja usia 13-15 tahun termasuk masa peralihan dari remaja awal ke remaja akhir yang merupakan masa pencarian identitas sehingga mudah terpengaruh lingkungan sekitar. Oleh karena itu, remaja berisiko tinggi mengalami gangguan gizi karena pada usia remaja mengalami peningkatan kebutuhan zat gizi, kebiasaan membatasi konsumsi makan dan pola konsumsinya yang sering menyimpang dari kaidah ilmu gizi (Arisman, 2009). Remaja membatasi asupan makan akibat kecemasan terhadap bentuk tubuhnya atau memilih makan di luar bersama teman-temannya. Kebiasaan ini mengakibatkan remaja mengalami kerawanan pangan yang berhubungan dengan asupan gizi.

Status gizi berkaitan dengan konsumsi makanan, bila makanan yang dikonsumsi mengandung zat besi dan memiliki nilai yang baik maka status gizi dari seseorang akan baik juga, sebaliknya bila makanan yang dikonsumsi tidak mengandung zat besi dan tidak memiliki nilai gizi yang baik maka akan menyebabkan kekurangan gizi dan dapat menyebabkan anemia defisiensi besi (Hapzah dkk, 2012). Salah satu masalah gizi remaja adalah anemia (Khomsan, 2010; Depkes, 2010). Kondisi anemia atau kadar hemoglobin rendah akan mempengaruhi pencapaian kognitif dan Performance Intelligence Quotient yang meliputi aspek memori spasial, kemampuan visual-persepsi, dan ketrampilan psikomotor. Ada beberapa faktor penyebab anemia pada remaja yaitu kurangnya 
pengetahuan, kebiasaan makan yang salah, haid (menstruasi), perdarahan, indeks massa tubuh (IMT), infeksi dan kondisi sosial ekonomi orang tua remaja (Almatsier, 2009). Remaja usia 13-15 tahun berisiko mengalami anemia karena keterbatasan intake pangan (protein hewani) juga akibat menstruasi dan meningkatnya kebutuhan zat besi selama grow spurt. Data berdasarkan Riskesdas (2013) juga menunjukkan prevalensi anemia remaja usia $<15$ tahun masih tinggi yaitu 26,4\% (Depkes, 2010).

Berdasarkan uraian di atas maka peneliti tertarik melakukan penelitian tentang hubungan anemia dan prestasi belajar dengan indeks massa tubuh (IMT) pada remaja putri kelas VIII di Surakarta.

\section{Metode Penelitian}

\section{Alat}

Untuk memperoleh data dalam penelitian ini dibutuhkan alat penelitian sebagai berikut : alat untuk pengambilan darah, timbangan berat badan injak yang sudah terstandarisasi dengan ketelitian 1000 gram., pengukur tinggi badan (microtoise) yang sudah terstandarisasi dengan ketelitian $0,1 \mathrm{~cm}$.

\section{Bahan}

Adapun bahan yang dipergunakan dalam penelitian ini adalah : blangko persetujuan (informed consent), kuesioner data diri responden dan dokumen nilai ujian akhir semester genap

\section{Tahapan Penelitian}

Jenis penelitian ini adalah penelitian kuantitatif observasional analitik (non-experiment) dengan menggunakan pendekatan cross sectional. Pengambilan sampel menggunakan teknik random sampling yang dilakukan di SMP Negeri 3 Surakarta dan SMP Negeri 7 Surakarta, Kecamatan Banjarsari, Kota Surakarta.

Kriteria sampel penelitian adalah seluruh remaja putri kelas 2 di SMP Negeri 3 Surakarta dan SMP Negeri 7 Surakarta yang berstatus aktif pada semester genap tahun ajaran 2014/2015, berusia 1315 tahun, bersedia menjadi responden, tidak sedang mengkonsumsi suplemen zat besi, sedang tidak sakit infeksi (TBC, diare, tumor, jantung) dan sedang tidak menstruasi saat pemeriksaan. Untuk mendapatkan sampel dengan kriteria di atas, peneliti membagikan kuesioner kepada calon responden, kemudian yang memenuhi kriteria di atas baru dilakukan pemeriksaan oleh petugas laboratorium. Data yang dikumpulkan merupakan data primer kemudian dilakukan uji normalitas data dengan uji Kolmogorov-Smirnov.

\section{Analisa Data}

Analisis data menggunakan computer program SPSS 17.0 for windows yang meliputi analisis univariat dan bivariat. Analisis univariat untuk menggambarkan karakteristik berat badan, tinggi badan, umur dan IMT/U remaja putri, kadar $\mathrm{Hb}$,nilai rata-rata ujian akhir semester genap ajaran 2014/2015. Sedangkan analisis bivariat untuk perhitungan nilai mean, standart deviasi, maksimum dan minimum. Sedangkan analisis bivariat menggunakan uji Korelasi Pearson untuk mengetahui hubungan antara variabel anemia dan prestasi belajar dengan IMT

\section{Hasil dan Pembahasan}

Penelitian ini dilaksanakan di dua Sekolah Menengah Pertama (SMP) di Kecamatan Banjarsari Kota Surakarta, Jawa Tengah, yaitu SMP Negeri 3 Surakarta dan SMP Negeri 7 Surakarta. SMP Negeri 3 Surakarta. Berdasarkan hasil penelitian dengan metode cross-sectional diperoleh 120 orang dengan distribusi 60 remaja putri kelas VIII pada SMP Negeri 3 Surakarta dan 60 remaja putri kelas 2 pada SMP Negeri 7 Surakarta. Data yang dikumpulkan kemudian dilakukan uji normalitas data dengan uji Kolmogorov-Smirnov karena sampel yang diambil lebih dari 50 sampel dan didapatkan tidak semua data terdistribusi normal. Pada penelitian ini dikatakan berdistribusi normal jika nilai $\mathrm{p}>0,05$ (Dahlan, 2011). Data kemudian dilakukan analisis bivariat melihat hubungan antara variabel bebas dan terikat. Tabel I. Hasil Analisis Distribusi Subjek Menurut Variabel (Terlampir).

Pada Tabel I ditunjukkan distribusi berdasarkan Indeks Massa Tubuh (IMT) yang dinilai menggunakan z-skor didapatkan subjek penelitian dengan kategori sangat kurus 1 (8\%), kurus 12 $(10 \%)$, gemuk 3 orang $(2,5 \%)$ dan frekuensi yang paling banyak adalah status gizi normal yaitu sebanyak $104(86,7 \%)$ dan penilaian anemia yang dinilai berdasarkan kadar $\mathrm{Hb}$ didapatkan siswa remaja putri yang mengalami anemia ringan sebanyak $12(10 \%)$, sedangkan subjek penelitian yang nilai hemoglobinnya normal sebanyak 108 $(90 \%)$. Distribusi data berdasarkan prestasi belajar mata pelajaran sekolah didapatkan mata pelajaran yang 100\% lulus adalah Pendidikan Agama, adapun yang jumlah subjek tidak lulus adalah mata pelajaran matematika sebanyak 59 (49,16\%). Batasan nilai lulus apabila hasil UAS tiap mata pelajaran $>69$. 
Pada penelitian ini untuk mengetahui hubungan antara anemia yang dinilai dengan melihat kadar $\mathrm{Hb}$ terhadap prestasi belajar yang dilihat dari rata-rata nilai hasil ujian akhir semester (UAS) siswa remaja putri SMP kelas VIII di Surakarta dengan IMT digunakan analisis bivariat. Berdasarkan uji korelasi Pearson antara anemia dengan IMT didapatkan hasil sebagai berikut :

Tabel II. Korelasi Pearson antara anemia dengan IMT

\begin{tabular}{cccccc}
\hline $\begin{array}{c}\text { Variabel } \\
\text { bebas }\end{array}$ & $\begin{array}{c}\text { Variabel } \\
\text { terikat }\end{array}$ & $\mathrm{r}$ & $\mathrm{P}$ & Exp & Sig. \\
\hline Anemia & IMT & 0.201 & 0.024 & 4.255 & 0.035
\end{tabular}

Berdasarkan Tabel II di dapatkan nilai $\mathrm{r}=$ 0,201 , odd rasio sebesar 4,255 dan $p=0,35$, hal ini berarti terdapat hubungan antara anemia dengan IMT pada remaja putri SMP kelas VIII. Dengan kata lain, apabila ada remaja putrid mengalami penurunan IMT mengakibatkan anemia sebesar 4,25 kali. Dapat dilihat dengan diagram plot di bawah ini

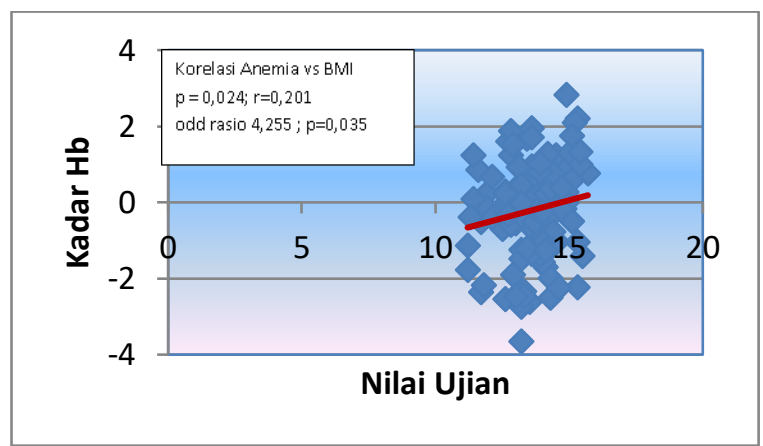

Gambar 1. Diagram Plot Korelasi Anemia dengan IMT

Sedangkan hasil analisis bivariat yang mengubungkan antara prestasi belajar dengan IMT dapat dilihat di bawah ini :

Tabel III. Korelasi Pearson antara prestasi belajar dengan IMT

\begin{tabular}{lccccc}
\hline $\begin{array}{c}\text { Variabel } \\
\text { bebas }\end{array}$ & $\begin{array}{c}\text { Variabel } \\
\text { terikat }\end{array}$ & $\mathrm{r}$ & $\mathrm{p}$ & Exp & Sig. \\
\hline $\begin{array}{l}\text { Prestasi } \\
\text { belajar }\end{array}$ & IMT & 0.093 & 0.307 & 0.0 & 0.999 \\
\hline
\end{tabular}

Tabel III menunjukkan hasil $\mathrm{r}=0.093$ dengan odd rasio $=0,307$ dan $p=0.999$. Hal ini berarti tidak ada hubungan antara prestasi belajar dengan IMT.

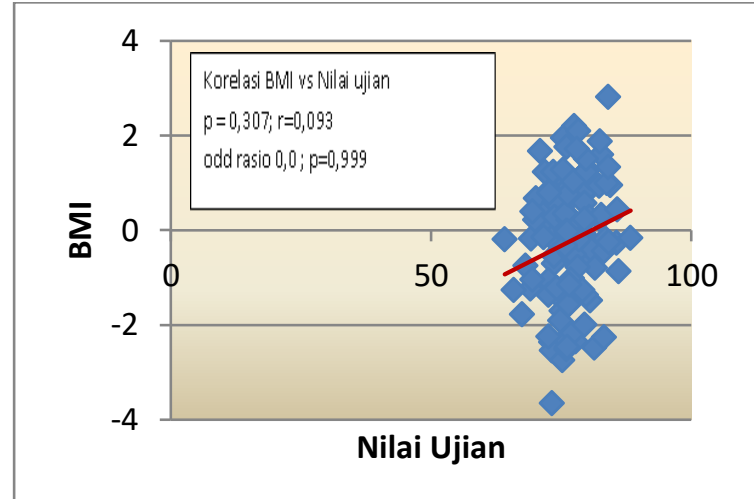

Gambar 2. Diagram Plot Korelasi Prestasi Belajar dengan IMT

Berdasarkan hasil penelitian menurut umur didapat bahwa sebagian besar subyek penelitian berumur diantara 12-15 tahun. Ini sesuai dengan teori perkembangan anak yang dikemukan oleh menurut Hurlock (2012) bahwa masa remaja adalah yang berada pada usia antara 12-18 tahun.

Subyek penelitian menunjukkan rata-rata nilai IMT dalam kategori status gizi normal. Status gizi adalah gambaran keadaan tubuh akibat konsumsi, penyerapan dan penggunaan zat-zat gizi atau keadaan fisiologik akibat dari tersedianya zat gizi dalam tubuh (Supariasa, 2002). Status gizi yang baik menggambarkan konsumsi makanan dan kondisi kesehatan yang baik dari subyek penelitian (Supariasa, 2002).

Penilaian status gizi dilakukan berdasarkan indikator IMT/U lebih dipengaruhi oleh asupan zat gizi makro (karbohidrat, lemak, protein) (Muchlisa, 2013). Banyak faktor yang mempengaruhi status gizi normal diantaranya adalah status sosial ekonomi, pendapatan keluarga berpengaruh langsung terhadap daya beli keluarga. Meningkatnya pendapatan berarti memperbesar peluang untuk membeli pangan dengan kualitas dan kuantitas yang baik (Supariasa, 2002). Indeks Massa Tubuh (IMT) merupakan indikator yang paling sering digunakan untuk mendeteksi masalah gizi pada seseorang (Supariasa, 2002). Khusus untuk anak dan remaja pengukuran status gizi menggunakan IMT yang terkait dengan umur, dengan alasan karena pada anak dan remaja apabila terjadi perubahan umur akan diikuti terjadinya perubahan komposisi tubuh dan densitas tubuh. Pengukuran status gizi remaja digunakan indikator IMT menurut umur, biasa disimbolkan dengan IMT/U. 
Penilaian anemia dilakukan dengan menilai kadar hemoglobin responden dan didapatkan ratarata memiliki nilai hemoglobin termasuk normal (tidak anemia). Kadar hemoglobin normal dipengaruhi oleh konsumsi protein dan zat besi dalam tubuh. Protein dan zat besi sangat diperlukan dalam proses metabolisme hemoglobin dalam tubuh (Widyastuti dan Hardiyanti, 2008). Semakin tinggi asupan zat besi, semakin tinggi juga kadar hemoglobin dalam darah, dimana hemoglobin berperan dalam transpoter oksigen. Nilai batas normal kadar hemoglobin untuk remaja putri adalah $<12 \mathrm{gram} / \mathrm{dL}$ (WHO, 2000).

Berdasarkan hasil penelitian menunjukkan bahwa $81,81 \%$ responden memiliki hasil prestasi belajar yang baik. Prestasi belajar adalah hasil belajar siswa selama satu semester yaitu diambil dari semester II sebagai indikator pengukuran kemampuan kognitif. Hal ini dikarenakan aspek kognitif sebagai tujuan utama aspek pendidikan di setiap proses belajar mengajar di sekolah (Herliana dan Indrawati, 2009). Kemampuan yang tercakup dalam aspek kognitif adalah pengetahuan, pemahaman, aplikasi, analisis dan sintesis yang diberikan sebelumnya dalam sebuah pelajaran teori di kelas.

Pada penelitian ini diambil semua mata pelajaran untuk menunjukkan kemampuan kognitif siswa meliputi : Pendidikan Agama, Pendidikan Kewarganegaraan, Bahasa Indonesia, Bahasa Inggris, Matematika, Ilmu Pengetahuan Alam (IPA), Ilmu Pengetahuan Sosial (IPS), Seni Budaya, Pendidikan Jasmani, Teknologi Informasi dan Komunkasi dan Bahasa Jawa Tercapainya prestasi belajar yang baik didukung dengan terpenuhinya sarana dan prasarana serta metode pembelajaran yang baik, maka proses belajar akan semakin baik juga, dan pada akhirnya akan meningkatkan prestasi belajar. Ada beberapa faktor yang mempengaruhi keberhasilan belajar yaitu faktor internal dan eksternal. Sedangkan faktor eksternal dipengaruhi oleh lingkungan keluarga, sarana keluarga, dan guru. Misalnya, letak sekolah atau tempat belajar merupakan salah satu faktor non sosial yang mempengaruhi proses belajar dan hasil belajar (Suryabrata, 2011). Faktor internal adalah faktor yang berasal dari dalam diri individu itu sendiri terdiri dari faktor biologis dan faktor psikologis, status gizi yang dipengaruhi juga oleh asupan energi dan protein. Keterkaitan faktor internal yang harus diwaspadai adalah kebutuhan energy yang didapatkan dari status gizi. Hal ini karena sangat kebutuhan energi dibutuhkan pada proses pembelajaran anak. Anak sekolah dengan status gizi kurang atau buruk berdampak pada gangguan perkembangan otak menjadi tidak sempurna. Efek dari perkembangan otak yang tidak sempurna menyebabkan kognitif, perkembangan IQ terhambat dan kemampuan belajar terganggu yang selanjutnya berpengaruh pada prestasi belajar siswa (Soekirman, 2000).

Hasil analisis data menunjukkan ada hubungan antara anemia dengan IMT dan tidak ada hubungan antara prestasi belajar dengan IMT. Penelitian ini sejalan dengan variabel pengukuran status gizi berdasarkan $\mathrm{TB} / \mathrm{U}$ berdasarkan prestasi belajar pernah dilakukan oleh Nuryati (2002) dan Enizarti (2001) yang menyatakan tidak ada hubungan status gizi yang dinilai dengan TB/U dengan prestasi belajar. Penelitian ini menunjukkan bahwa populasi yang diteliti, IMT sebagai gambaran status gizi yang dihitung dalam z-score bukanlah faktor utama yang dapat mempengaruhi prestasi belajar siswi remaja putri SMP kelas VIII di Surakarta. Beberapa faktor yang mungkin mempengaruhi proses dan prestasi belajar ialah tingkat kecerdasan (Farokah, 2007), pengaturan waktu belajar serta menyediakan alat belajar, dan konsumsi gizi yang seimbang. Jika konsumsi gizi yang masuk kedalam tubuh baik, maka status gizinya juga baik pula. Penelitian ini senada dengan penelitian yang dilakukan oleh Setyaningsih (2003) yang menyatakan bahwa tidak ada perbedaan yang signifikan pada prestasi belajar berdasarkan IMT pada siswa SMK Katholik Klaten yang menyatakan bahwa prestasi belajar tidak hanya dipengaruhi oleh status kesehatan (status gizi) saja melainkan banyak faktor lain yang mempengaruhinya. Penelitian serupa juga dilakukan oleh Kurniati (2007) yang menyatakan bahwa tidak ada hubungan status Hemoglobin dengan hasil tes mata pelajaran Matematika ( $p$-value $=0,076$ dan tidak ada hubungan kadar hemoglobin dengan tes bahasa Indonesia $(\mathrm{p}$-value $=0,10)$.

Hasil penelitian yang tidak sejalan diantaranya penelitian yang dilakukan oleh Listiyorini (2011), yang menyatakan ada hubungan positif dan signifikan antara status gizi dan prestasi belajar dengan nilai $\mathrm{p}=0,037$, yang berarti semakin baik status gizinya akan semakin baik pula prestasi belajarnya. Hasil penelitian ini sejalan dengan penelitian yang dilakukan oleh Khoirunisa (2012) dari hasil analisis bivariat menunjukan hubungan Status Gizi dengan IPK diperoleh nilai $\mathrm{p}=0,000$ dengan nilai $r=<0,05$ maka dapat disimpulkan adanya hubungan yang signifikan antara status gizi dengan IPK, pada uji statistik diperoleh juga nilai or $=9,77$. 
Saat ini prevalensi anemia gizi besi anak sekolah di Indonesia sebesar 26,5\%. Zat besi adalah komponen penting hemoglobin. Hemoglobin mengandung besi yang disebut hem dan protein globulin. Setiap molekul hemoglobin mengikat oksigen untuk diedarkan ke seluruh tubuh (Corwin, 2006). Jika seseorang mengalami kejadian anemi gizi besi dapat menyebabkan transport oksigen menjadi berkurang, dan mengakibatkan produksi energy menjadi rendah sehingga anak menjadi mudah lelah, letih, lemah, lesu, lalai, cepat capai, kurang konsentrasi. Selanjutnya dapat berakibat dapat menurunnya prestasi belajar, produktifitas kerja termasuk olah raga serta menurunkan daya tahan tubuh. Pada remaja putri, kebutuhan yang tinggi akan besi terutama disebabkan kehilangan zat besi selama menstruasi (Nurhaedar, 2012). Hal ini sesuai dengan penelitian Agustina (2012) yang menyatakan bahwa kadar hemoglobin bukanlah satu-satunya faktor yang mempengaruhi hasil belajar seseorang. Faktor lain yang berhubungan dengan prestasi belajar yaitu motivasi. Motivasi adalah salah satu faktor yang dapat mempengaruhi hasil belajar anak sekolah. Apabila motivasi cukup baik dalam belajar akan berpengaruh pada prestasi belajar siswi SMP kelas VIII di Surakarta. Motivasi belajar memiliki pengaruh yang signifikan terhadap hasil belajar atau prestasi belajar (Agustin, 2013). Motivasi merupakan penggerak atau pendorong untuk melakukan sesuatu Hal tersebut mencerminkan bahwa seseorang yang memiliki kadar hemoglobin baik atau tidak anemia belum tentu memiliki prestasi belajar yang baik jika tidak diimbangi dengan motivasi belajar yang tinggi pula. Motivasi belajar yang tinggi bisa didapatkan jika ada dukungan dari lingkungannya seperti lingkungan sosial, lingkungan keluarga, sarana maupun prasarana di lingkungan akademik yang mendukung. Selain itu diperlukan motivasi dari orang tua serta guru kepada anak didik untuk dapat meningkatkan hasil belajar. Dalam hal ini hasil belajar juga ditentukan oleh tingkat kecerdasan siswi. Tingkat kecerdasan sangat menentukan berhasil atau tidaknya seorang siswi dalam belajar. Semakin tinggi tingkat kecerdasan siswi, semakin baik pula nilai hasil belajar yang diperoleh (Syah, 2006).

Kadar hemoglobin dipengaruhi oleh banyaknya kadar asupan protein dan zat besi. Banyaknya kadar asupan protein dan zat besi memiliki hubungan yang signifikan dengan prestasi belajar siswa. Anemia tara lain mempengaruhi daya fikir, pertumbuhan dan imunitas. Dampak anemia terhadap daya fikir akan mempengaruhi remaja di dalam berprestasi disekolah. Anemia dapat menurunkan IQ sekitar 5-10 \%. Anemia juga berdampak pada imunitas sehingga mempengaruhi menurunnya produktivitas secara tidak langsung melalui seringnya tidak masuk sekolah karena sakit (Word Bank, 2006 dan Supariasa, 2002).

\section{Simpulan}

Terdapat korelasi antara anemia dengan IMT pada remaja putri sekolah menengah tingkat pertama kelas 2. Tidak terdapat korelasi antara prestasi belajar dengan IMT pada remaja putrid kelas 2 sekolah menengah di Surakarta.

\section{Ucapan Terima Kasih}

Terima aksih diberikan kepada siswa SMP Negeri 3 dan SMP Negeri 7 Surakarta yang telah berpartidipasi aktif dalam penelitian ini, Laboratorium Parahita Cabang Surakarta dan semua pihak yang telah membantu dalam menyelesaikan penelitian ini.

\section{Daftar Pustaka}

Agustina, Lisa. 2012. Pengaruh Motivasi Belajar Siswa Terhadap Hasil Belajar IPA Siswa Kelas IV di SDN Taruma Negara Kecamatan Tawang Kota Tasikmalaya. Jurnal Pendidikan Dasar Vol. 11 No. 1 April 2012.

Agustin, V.N., 2013. Peningkatan Aktivitas dan Hasil Belajar Siswa Melalui Metode Problem Based Learning (PBL). Journal Of Elementary Education (2) 1: 39-43.

Almatsier, S. 2009. Prinsip Dasar Ilmu Giz̨i. Jakarta: PT. Gramedia Pustaka Utama.

Arisman. 2009. Gizi dalam Daur Kehidupan. Jakarta: Penerbit Buku Kedokteran EGC.

Corwin, RL., 2006. Bingeing rats : a model of intermittent excessive behaviour? Appetite 46: 11-15.

Departemen Kesehatan RI., 2010. Rencana Pembangunan Kesehatan Menuju Indonesia Sehat 2015. www.depkes.go.id.

Departemen Kesehatan RI., 2010. Kesehatan Remaja Problem dan Solusinya. Jakarta: Medika.

Enizarti, 2001. Hubungan Status Gizi dan FaktorFaktor Lain Dengan Prestasi Belajar Murid SDN 03 Kelurahan Gandaria Kecamatan Cilandak Jakarta Selatan. Skripsi. Fakultas Kesehatan Mayarakat Universitas Indonesia.

Farokah, Suprihati, Suyitno S., 2007. Hubungan Tonsilitis Kronis Dengan Prestasi Belajar Pada Siswa Kelas II Sekolah Dasar di Kota 
Semarang dalam Riyanto WB, editor. Cermin Dunia Kedokteran. No. 155. 34 (2).

Hapzah: Yulita, R. 2012. Hubungan Pengetahuan dan Status Gizi terhadap Kejadian Anemia Remaja Putri Pada Siswi Kelas III di SMAN 1 Tinambung Kabupaten Polewali Mandar. Media Gizi Pangan Vol XIII Edisi 1.

Hardinsyah, Riyadi., H., dan Napitupulu, V., 2012. Kecukupan Energi Proteinn, Lemak dan Karbobidrat., Jakarta : Widyakarya Nasional Pangan dan Gizi.

Herlina, Elly dan Indrawati, 2009. Penilaian Hasil Belajar. Jakarta : Pusat Pengembangan Pemberdayaan Pendidik dan Tenaga Kependidikan Ilmu Pengetahuan Alam.

Hurlock, 2012. Perkembangan Anak Jilid 2. Jakarta: Erlangga.

Kurniati, Teti, 2007. Perpustakaan Sebagai Sarana Penunjang Keberbasilan Siswa. Jakarta: Universitas Terbuka.

Khairunnisa, Anjani, 2012. Hubungan Status Gizi Dengan Indeks Prestasi Komulatif Mahasiswa Akademi Kebidanan. Skripsi. Universitas Diponegoro.

Khomsan, A., 2010. Pangan dan Gir̨i Untuk Kesehatan. Jakarta: PT.Raja Grafindo Persada.

Listiyorini, Dyah, 2011. Hubungan Asupan Energi dan Status Gizi Dengan Prestasi Belajar Siswa Sekolah Dasar di Kecamatan Baki Kabupaten Sukoharjo. Skripsi. Universitas Sebelas Maret.

Muchlisa, 2013. Hubungan Asupan Gizi Dengan Status Gizi Pada Remaja Putri di Fakultas Kesehatan Masyaraat Universitas Hasanudin Makasar, Skripsi. Jurusan Kesehatan Masyarakat

Nurhadi, dkk., 2004. Pembelajaran Kontekstual dan Penerapannya Dalam KBK. Malang: UM Press.
Nurhaedar, Jafar. 2012. Defisiensi Karbohidrat dan Protein Pada Kejadian Gizi Buruk Balita. Artikel Penelitian. Universitas Hasanuddin Makasar.

Nuryati, 2002. Pemahaman Konsep (online). Dapat dilihat http://pembelajarankooperatif.com

Ristianingrum I., Rahmawati I., Rujito L., 2010. Hubungan Antara Indeks Massa Tubuh (IMT) Dengan Tes Fungsi Paru. Mandala Of Health. 4 (2): 105-112

Setyaningsih, Retno, 2003. Perbedaan Prestasi Belajar Siswi SMK Katolik Klaten Berdasarkan Status Gizi (HB dan IMT). Skripsi. Universitas Diponegoro

Supariasa, dkk., 2002. Penilaian Status Giri. Jakarta: EGC.

Soekirman, 2000. Ilmu Gizi dan Aplikasinya Untuk Keluarga dan Masyarakat. Direktorat Jenderal Pendidikan Tinggi Departemen Pendidikan Nasional, Jakarta.

Soetjiningsih, 2012. Buku Ajar Ilmu Perkembangan Anak dan Remaja. Jakarta: Sagungseto.

Suryabrata, Sumadi, 2011. Psikologi Pendidikan, Jakarta: PT. Raja Grafindo Persada.

Syah, M., 2006. Psikologi Belajar. Jakarta: Raja Grafindo .

Syah, M., 2010. Psikologi Pendidikan dengan Pendekatan Baru. Bandung : Remaja Rosda Karya.

Tim Penulis Poltekkes Depkes Jakarta I, 2010. Kesehatan remaja; problem dan solusinya. Jakarta: Salemba Medika.

Widyastuti, P; Hardiyanti, E. A., 2008. Gir̨i Kesehatan Masyarakat. Jakarta EGC

World Bank, 2002. World Development Report 2002: Building Institution For Market. New York : Oxford University Press. 


\section{LAMPIRAN}

Tabel I. Hasil Analisis Distribusi Subjek Menurut Variabel

\begin{tabular}{|c|c|c|c|c|c|c|}
\hline $\mathrm{No}$ & Karakteristik & Min & Maks & Rerata $\pm S D$ & $\mathrm{~N}$ & $\%$ \\
\hline 1 & Umur & 12 & 15 & $13.64 \pm 0.53$ & & \\
\hline \multirow[t]{5}{*}{1} & Status Gizi & $-3,64$ & 2,83 & $-0,21 \pm 1,24$ & 120 & 100 \\
\hline & a. Sangat Kurus & & & & 1 & 8 \\
\hline & b. Kurus & & & & 12 & 10 \\
\hline & c. Normal & & & & 104 & 86,7 \\
\hline & d. Gemuk & & & & 3 & 2,5 \\
\hline \multirow[t]{3}{*}{2} & Anemia & 11,20 & 15,70 & $13,55 \pm 1,04$ & & \\
\hline & a. Ringan & & & & 12 & 10 \\
\hline & b. Normal & & & & 108 & 90 \\
\hline \multirow[t]{34}{*}{3} & Prestasi belajar & & & & & \\
\hline & a. Pendidikan Agama & 73.00 & 97.00 & $85,05 \pm 4.79$ & & \\
\hline & - Lulus & & & & 120 & 100 \\
\hline & - Tidak lulus & & & & 0 & 0 \\
\hline & b. PKn & 64.00 & 95.00 & $86.18 \pm 6.21$ & & \\
\hline & - Lulus & & & & 118 & 98,33 \\
\hline & - Tidak lulus & & & & 2 & 1,67 \\
\hline & c. Bahasa Indonesia & 65.00 & 93.00 & $82.36 \pm 4.84$ & & \\
\hline & - Lulus & & & & 119 & 99,17 \\
\hline & - Tidak lulus & & & & 1 & 0,83 \\
\hline & d. Bahasa Inggris & 36.00 & 94.00 & $68.51 \pm 10.31$ & & \\
\hline & - Lulus & & & & 47 & 0,39 \\
\hline & - Tidak lulus & & & & 63 & 52,5 \\
\hline & e. Matematika & 32.00 & 98.00 & $67.96 \pm 13.68$ & & \\
\hline & - Lulus & & & & 61 & 0,50 \\
\hline & - Tidak lulus & & & & 59 & 49,16 \\
\hline & f. IPA & 47.00 & 95.00 & $72.50 \pm 8.59$ & & \\
\hline & - Lulus & & & & 84 & 70 \\
\hline & - Tidak lulus & & & & 36 & 30 \\
\hline & g. IPS & 56.00 & 91.00 & $77.27 \pm 6.88$ & & \\
\hline & - Lulus & & & & 104 & 86,67 \\
\hline & - Tidak lulus & & & & 16 & 13,33 \\
\hline & h. Seni budaya & 60.00 & 93.00 & $76.14 \pm 6.42$ & & \\
\hline & - Lulus & & & & 105 & 87,5 \\
\hline & - Tidak lulus & & & & 15 & 12,5 \\
\hline & i. Pendidikan Jasmani & 66.00 & 91.00 & $80.33 \pm 4.93$ & & \\
\hline & - Lulus & & & & 118 & 98,33 \\
\hline & - Tidak lulus & & & & 2 & 1,67 \\
\hline & j. TIK & 50.00 & 93.00 & $78.91 \pm 10.09$ & & \\
\hline & - Lulus & & & & 96 & 80 \\
\hline & - Tidak lulus & & & & 24 & 20 \\
\hline & k. Bahasa Jawa & 47.00 & 94.00 & $72.54 \pm 8.27$ & & \\
\hline & - Lulus & & & & 79 & 65,83 \\
\hline & - Tidak lulus & & & & 41 & 34,17 \\
\hline
\end{tabular}

